\title{
Dietary DHA: time course of tissue uptake and effects on cytokine secretion in mice
}

\author{
Jennifer Lefils, Alain Géloën, Hubert Vidal, Michel Lagarde and Nathalie Bernoud-Hubac* \\ Université de Lyon, UMR 870 INSERM, Insa-Lyon (RMND-IMBL), Univ Lyon 1, Inra 1235, Hospices Civils de Lyon, F-69621 \\ Villeurbanne, France
}

(Received 11 November 2009 - Revised 7 April 2010 - Accepted 23 April 2010 - First published online 21 May 2010)

Consumption of DHA has numerous beneficial effects, but little is known about these effects during the first few days of the DHA dietary intake. The main objectives of the present study were to determine the time course of DHA incorporation into phospholipids in different mouse tissues and the effects of DHA supplementation on adiponectin and leptin secretion. Mice were fed either a control diet or a DHA-rich diet, and some were killed on days $0,4,8,16$ and 32. Some mice were fed the DHA-rich diet for $16 \mathrm{~d}$, and were then maintained on the control diet for sixteen more days (washout period). DHA supplementation increased plasma adiponectin secretion by $2 \cdot 4$-fold as early as $4 \mathrm{~d}$ after the initiation of the DHA-rich diet feeding. The adiponectin concentration remained 1·6-fold higher after the $16 \mathrm{~d}$ washout period. Plasma leptin levels were significantly lower after $4 \mathrm{~d}$ of feeding with DHA. These effects were associated with a significant increase in DHA incorporation in phosphatidylethanolamine and phosphatidylcholine of all analysed tissues (liver, heart and white adipose tissues). DHA mainly got incorporated at the expense of $n-6$ arachidonic acid. The present data show that DHA rapidly improved the profile of secreted adipokines, and that these protective effects were long lasting.

Docosahexaenoic acid: Adiponectin: Leptin: Mice

Intake of $n$-3 long-chain PUFA ( $n$-3 LC-PUFA), mainly EPA $(20: 5 n-3)$ and DHA $(22: 6 n-3)$, which are abundant in marine fish meat and oil, has many health benefits. These fatty acids (FA) can protect against CVD, and improve insulin sensitivity with protective effects against obesity ${ }^{(1-5)}$.

The mechanisms behind the beneficial effects of $n-3$ LCPUFA are numerous, including competitive inhibition with arachidonic acid (AA) conversion to pro-inflammatory eicosanoids, modification of the membrane enzyme activity ${ }^{(6)}$, modulation of gene expressions ${ }^{(7,8)}$ and change in the pattern of secreted adipocytokines. Adiponectin is an adipocyte secretory protein that exerts potent insulin-sensitising property in conjunction with anti-atherogenic and anti-inflammatory properties $^{(9-12)}$. Serum concentrations of adiponectin decrease in patients with type 2 diabetes, insulin resistance and obesity $^{(10,13-15)} \cdot n$-3 LC-PUFA have been shown to stimulate the secretion of adiponectin in mice fed a high-fat diet for a period of 5 weeks ${ }^{(16)}$. The induction of plasma adiponectin has also been observed in overweight human subjects in response to daily intake of $n-3$ LC-PUFA $^{(17)}$. $n$-3 LC-PUFA intake could also modify the secretion of other adipokines. Among them, leptin is also thought to provide a link between inflammation, insulin resistance and obesity ${ }^{(18,19)}$, but in contrast to adiponectin, leptin has pro-inflammatory effects ${ }^{(20-22)}$. Plasma leptin concentration has been shown to decline in mice fed fish oil diet for $15 \mathrm{~d}^{(23)}$.
One concern is that most studies have used fish oil to examine the benefical effects of $n-3$ LC-PUFA. However, these oils usually consist mainly of EPA and DHA and smaller amounts of other $n-3$ and $n-6$ PUFA. One study has examined the effect of dietary DHA on adipocytokine secretion in mice $^{(24)}$. In this study, DHA, rather than EPA, was shown to have the most pronounced effect on adiponectin induction. However, the study was conducted over a relatively long period (8-week feeding period). Another concern is that it is not known whether the protective effects of DHA are maintained after the arrest of the DHA-rich diet feeding. Moreover, while intake of DHA has been recommended, its kinetics of incorporation remains largely unknown, especially during the early days of dietary enrichment, and we know that the beneficial effects of $n$-3 LC-PUFA depend on the duration of their administration. Hence, it is critical to have a better understanding of the accretion of DHA. The effects of $n-3$ LC-PUFA result also from their interactions with several organ systems. Therefore, one aim of the present study was to determine the kinetics of DHA incorporation in different mouse tissues, following dietary supplementation. Membrane phospholipid FA composition was examined in liver, heart and white adipose tissues (WAT). The investigation of the effects of this DHA supplementation on cytokine production, especially adiponectin and leptin secretion, was most relevant. The $n-3$ LC-PUFA and adipokine concentrations have also

Abbreviations: AA, arachidonic acid; FA, fatty acids; $n$-3 LC-PUFA, $n$-3 long-chain PUFA; PC, phosphatidylcholine; PE, phosphatidylethanolamine; WAT, white adipose tissues.

* Corresponding author: N. Bernoud-Hubac, fax +33 4724385 24, email nathalie.bernoud-hubac@insa-lyon.fr 
been measured in animals submitted to a washout period equal to the length of supplementation.

\section{Experimental methods}

Animals and diets

Experiments were granted approval by the French Ministry of Agriculture, Fishing and Alimentation, and the Departmental Veterinary Agency of Rhône, and conducted using 3-weekold male International Cancer Research mice (Harlan, Gannat, France). All mice were treated in accordance with the European Communities Council Guidelines (24 November 1986, 86/609/EEC). Twenty-eight mice were randomly assigned to a standard diet A03 (SAFE, Augy, France) containing $5 \%$ lipids (control group), or to a DHA-enriched diet reconstituted with lipid-free powder (SAFE), $4.5 \%$ sunflower oil (Lesieur, Asnières-sur-Seine, France) and $0.5 \%$ 1,2,3-tridocosahexaenoylglycerol (Polaris, Pleuven, France) (experimental group). Both diets were nutritionally balanced. The complete nutrient and FA compositions of each of the diets are listed in Tables 1 and 2. Some mice were fed the DHA-enriched diet for $16 \mathrm{~d}$, and were then maintained on the standard diet for 16 more days (washout group). The food was prepared daily to avoid DHA peroxidation. All mice were fed ad libitum. TAG have been used for the DHA supplementation as they are quantitatively the most important lipid compounds in the human diet, and as they cause a good intestinal absorption (with efficiency higher than $95 \%$ ).

Mice were killed on days $0,4,8,16$ and 32 by lethal intraperitoneal injection of pentobarbitone $(1 \mu \mathrm{g} / \mu \mathrm{l})$ and weighed. Blood samples were collected, and plasma was obtained from the blood samples after centrifugation. Tissues and organs were dissected and immediately flash frozen in liquid $\mathrm{N}_{2}$ and stored at $-80^{\circ} \mathrm{C}$ until they were analysed.

\section{Lipids extraction and analyses}

Total lipids were extracted twice from tissue homogenates with ethanol-chloroform $(1: 2, \mathrm{v} / \mathrm{v})$. Before extraction, internal standards (1,2-diheptadecanoyl-sn-glycero-3-phosphocholine and 1,2-diheptadecanoyl-sn-glycero-3-phosphoethanolamine) were added. The organic phases were dried under $\mathrm{N}_{2}$, and the different phospholipid classes were then separated by TLC using the solvent mixture chloroform-methanolaqueous methylamine solution $(14 \%)(61: 19: 5$, v/v/v) as an eluent. Phosphatidylethanolamine (PE) and phosphatidylcholine (PC) were detected by spraying the silica gel plate with $0.2 \%$ dichlorofluorescein in ethanol. Silica gel was

Table 1. Nutrient composition of standard (A03) and DHA-rich diets

\begin{tabular}{lcc}
\hline Nutrients (mass \%) & Standard diet (A03) & DHA-rich diet \\
\hline Carbohydrates & 51.7 & 52.2 \\
Proteins & 21.4 & 19.0 \\
Lipids & 5.0 & 5.0 \\
Minerals & 5.7 & 6.6 \\
Fibres & 3.9 & 5.0 \\
Humidity & 12.2 & 12.0 \\
\hline
\end{tabular}

Table 2. Fatty acid composition of standard (A03) and DHA-rich diets

\begin{tabular}{lcc}
\hline Fatty acids $(\mathrm{mol} \%)$ & Standard diet (A03) & DHA-rich diet \\
\hline $16: 0$ & 22 & 5 \\
$16: 1$ & 2 & $\operatorname{tr}$ \\
$18: 0$ & 11 & 3 \\
$18: 1$ & 26 & 39 \\
$18: 2$ & 38 & 41 \\
$18: 3$ & tr & $\operatorname{tr}$ \\
$22: 6$ & nd & 10 \\
\hline
\end{tabular}

tr, trace; nd, non-detected.

scraped off, and PE and PC were extracted using a mixture of ethanol-chloroform (2:1, v/v). Each phospholipid was transmethylated, and the FA methyl esters were analysed by GC. Briefly, each fraction was treated separately with $500 \mu \mathrm{l}$ of toluene-methanol $(2: 3, \mathrm{v} / \mathrm{v})$ and $500 \mu \mathrm{l}$ of $14 \%$ boron trifluoride in methanol. Transmethylation was carried out at $100^{\circ} \mathrm{C}$ for $90 \mathrm{~min}$ in screw-capped tubes. The reaction was terminated by cooling the tubes to $0^{\circ} \mathrm{C}$ and by the addition of $1.5 \mathrm{ml} \mathrm{K}_{2} \mathrm{CO}_{3}$ in $10 \%$ water. The resulting FA methyl esters were extracted by $2 \mathrm{ml}$ of isooctane, and analysed by GC using a DELSI instrument model DI 200 equipped with a fused silica capillary SP-2380 column $(60 \times 0.22 \mathrm{~mm})$. He gas was used as the vector gas. Temperatures of the Ross injector and the flame ionisation detector were set at 230 and $250^{\circ} \mathrm{C}$, respectively.

\section{Multiplex analysis}

Concentrations of adipocytokines in sera were measured by the LINCOplex assay (LINCO Research, St Louis, MO, USA) following the manufacturer's instructions. In brief, the antibody-immobilised beads were incubated with standards, controls and samples in a ninety-six-well microtitre filter plate overnight at $2-4^{\circ} \mathrm{C}$. After washing the plate to remove excess reagents, detection antibody was added. Incubation was carried out for $30 \mathrm{~min}$ at room temperature, and streptavidin-phycoerythrin was then added for an additional $30 \mathrm{~min}$. After a final washing step, the beads were resuspended in a buffer, and were read using a laser-based detection instrument, the Luminex ${ }^{100}$, to determine the concentration of the cytokines of interest.

\section{Adiponectin and leptin measurement in adipose tissues}

Adipose tissues (AT) were homogenised in a buffer $(10 \mathrm{~mm}$ Tris- $\mathrm{HCl}, \mathrm{pH} 7 \cdot 4$, and $250 \mathrm{~mm}$-sucrose) containing a protease inhibitor cocktail. The mixture was then centrifuged at $10000 \mathrm{~g}$ for $5 \mathrm{~min}$. Adiponectin and leptin contents of the AT homogenates were measured by means of an ELISA (SpiBio, Montigny Le Bretonneux, France).

\section{Statistics}

Values are presented as means with their standard errors. The data were analysed using one-way ANOVA followed by Fisher's protected least significant difference (PLSD) post hoc tests, or using Student's paired $t$ test when appropriate. Different superscripts designate differences between groups at $P<0 \cdot 05$. 


\section{Results}

Body weight

Male mice were divided into two groups, and were fed a standard diet (control) or a diet supplemented with DHA for different times. Body weight gain of mice fed the DHA-rich diet was significantly lower than that of mice fed the standard diet (Fig. 1). This difference in body weight gain became significant as early as $4 \mathrm{~d}$ after the initiation of the DHA-rich diet feeding. After a $16 \mathrm{~d}$ washout period (mice fed the DHA-rich diet for $16 \mathrm{~d}$ and the standard diet for two other weeks), body weight of high-DHA diet-fed mice no longer differed from that of the standard diet-fed mice.

\section{Incorporation of DHA in liver, heart and white adipose tissues}

Figs. 2 and 3 show the DHA incorporation in PE and PC of liver, heart, subcutaneous, epididymal and retroperitoneal WAT. Proportions of DHA significantly increased in PE and PC of all tissues after only $4 \mathrm{~d}$ of DHA-enriched diet feeding.

In the liver (Figs. 2(A) and 3(A)), DHA proportions in PE did not get significantly higher beyond $4 \mathrm{~d}$, whereas proportions of DHA in PC continued to increase significantly until $8 \mathrm{~d}$ of high-DHA diet feeding. In both cases, there was no significant difference in the proportions observed on day 8 and day 16. The increase in DHA proportions reached $+116 \%$ in PE (27.6 (SEM 0.5) v. 12.8 (SEM 0.3) mol \%) and $+118 \%$ in PC (14.8 (SEM 0.4) v. 6.8 (SEM 0.2) mol \%) after 4 and $8 \mathrm{~d}$ of DHA-rich diet feeding, respectively. After a $16 \mathrm{~d}$ washout period, DHA proportions in $\mathrm{PE}$ and $\mathrm{PC}$ no longer differed from those found in the control mice.

In the heart (Figs. 2(B) and 3(B)), DHA proportions in PE and $\mathrm{PC}$ increased as a function of feeding time during the $32 \mathrm{~d}$ of DHA-rich diet feeding, reaching +96 and $+188 \%$ in $\mathrm{PE}$ and $\mathrm{PC}$, respectively, after $32 \mathrm{~d}$ of DHA-enriched feeding. In contrast to liver phospholipids, the proportions of DHA were still significantly higher in both phospholipids than those observed in mice fed the standard diet after the $16 \mathrm{~d}$ washout period.

In all three WAT, subcutaneous (Fig. 2(C)), epididymal (Figs. 2(D) and 3(D)) and retroperitoneal (Figs. 2(E) and 3(E)) tissues, DHA proportions in PE and PC were maximum on day 4 in mice fed the DHA-rich diet. Figs. 3(C)-(E) show that the proportions of DHA did not significantly differ

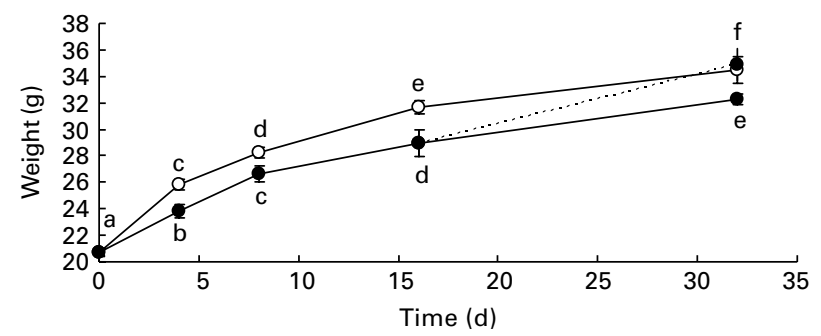

Fig. 1. Body weight gain (g) of mice fed a standard diet (control group - - -) and a DHA-rich diet (DHA group --) or mice fed a DHA-rich diet for the first $16 \mathrm{~d}$ and then the standard diet for the last $16 \mathrm{~d}$ (washout (WO) group --- -). Mice were killed on days $0,4,8,16$ and 32. Data are means with their standard errors $(n 60,28,20,20$ and 8 on days $0,4,8,16$ and 32 for the control group; $n 28,24,20$ and 8 on days $0,4,8,16$ and 32 for the DHA group and $n 4$ for the WO group). ${ }^{a, b, c, d, e, f}$ Mean values with unlike letters were significantly different $(P<0.05)$.
(A)

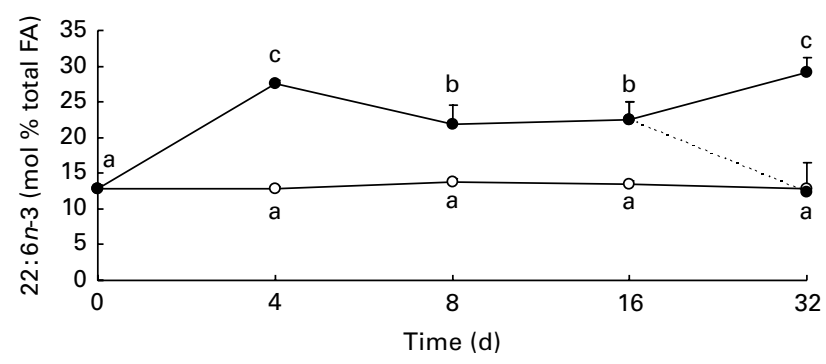

(B)

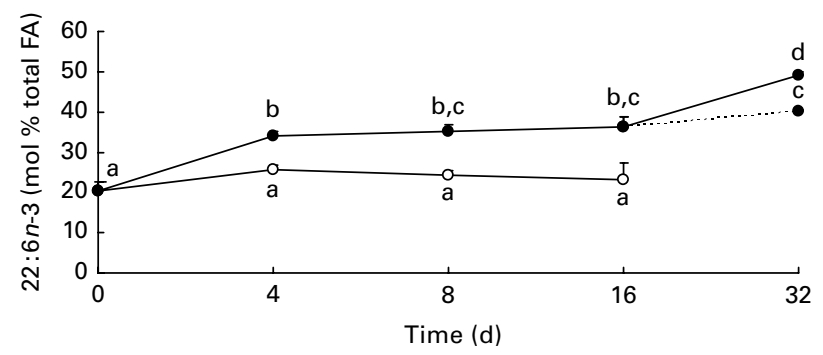

(C)

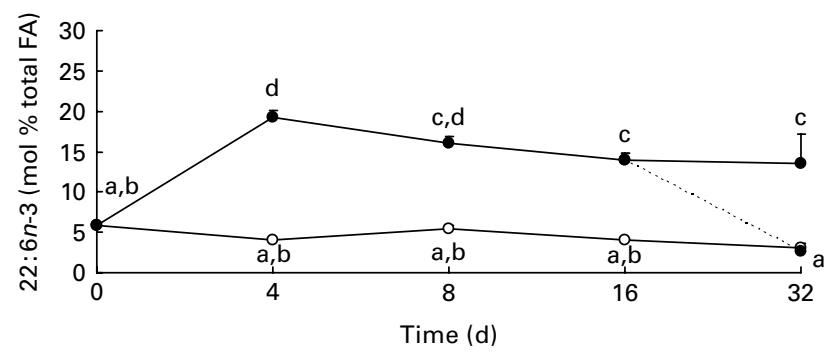

(D)

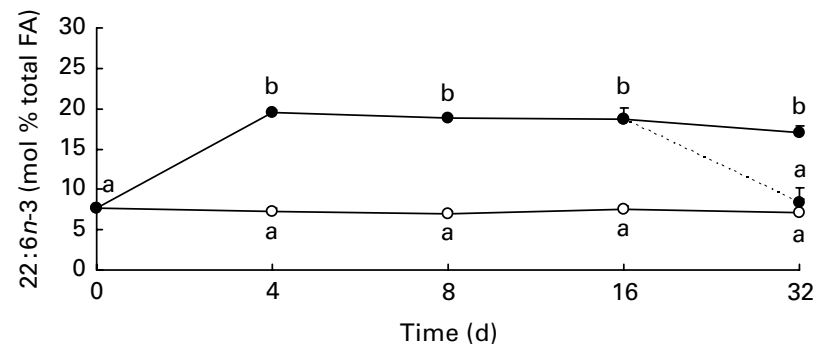

(E)

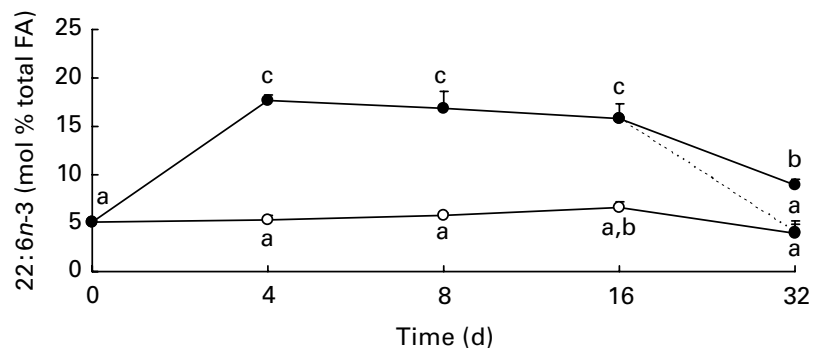

Fig. 2. $22: 6 n-3$ proportions in phosphatidylethanolamine from liver (A), heart (B) and subcutaneous (C), epididymal (D) and retroperitoneal adipose tissues (E) of mice fed a standard diet (control group -O-) and a DHA-rich diet (DHA group --) or mice fed a DHA-rich diet for the first $16 \mathrm{~d}$ and then the standard diet for the last $16 \mathrm{~d}$ (washout (WO) group --0--). Mice were killed on days $0,4,8,16$ and 32. Results are means with their standard errors $(n 4)$. ${ }^{a, b, c, d}$ Mean values with unlike letters were significantly different $(P<0.05)$. FA, fatty acids. 
between day 4 and day 16 in PC of WAT, and that they declined thereafter. The same observations can be made for the incorporation of DHA in PE of retroperioneal WAT (Fig. 2(E)). In subcutaneous and epididymal WAT, DHA

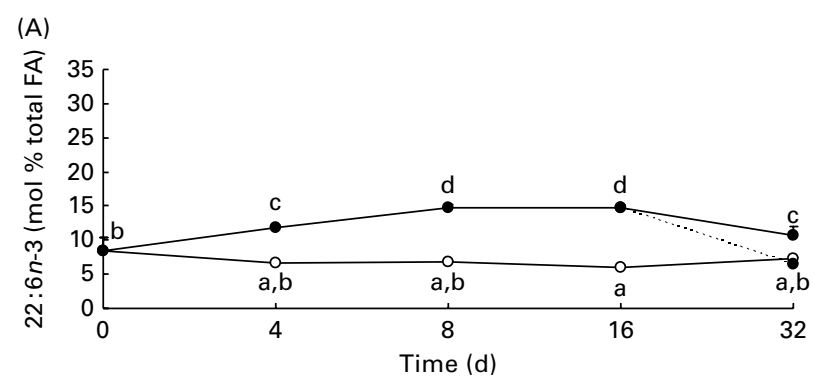

(B)

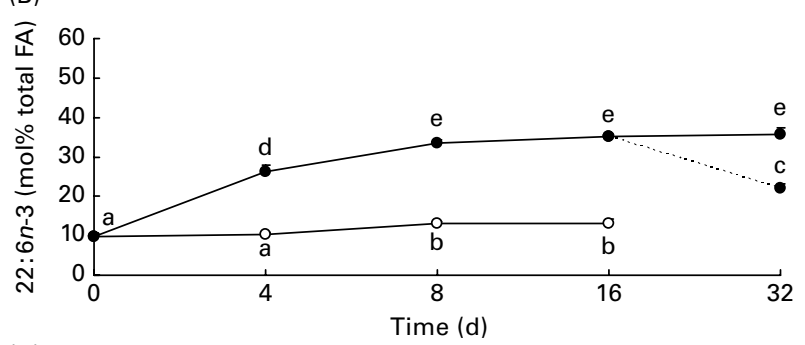

(C)

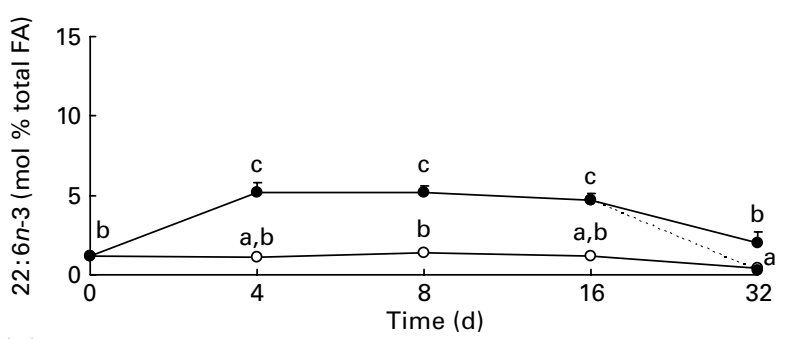

(D)

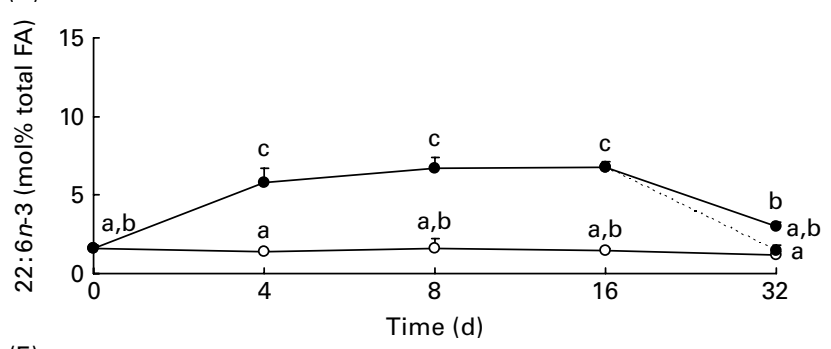

(E)

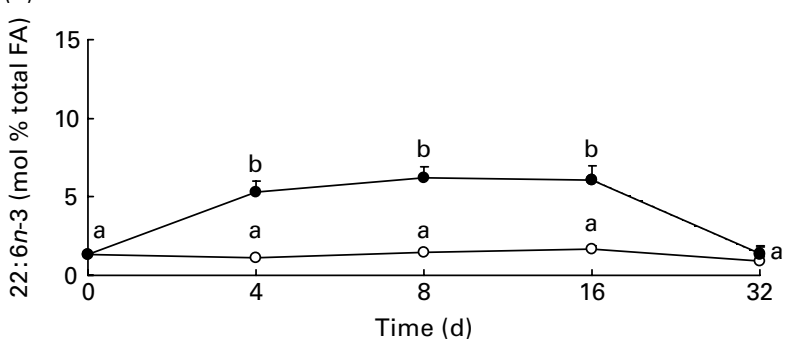

Fig. 3. 22: $6 n-3$ proportions in phosphatidylcholine from liver (A), heart (B) and subcutaneous $(C)$, epididymal $(D)$ and retroperitoneal adipose tissues (E) of mice fed a standard diet (control group -O-) and a DHA-rich diet (DHA group --) or mice fed a DHA-rich diet for the first $16 \mathrm{~d}$ and then the standard diet for the last $16 \mathrm{~d}$ (washout (WO) group -- -- -). Mice were killed on days $0,4,8,16$ and 32 . Results are means with their standard errors $\left(n\right.$ 4). ${ }^{a, b, c, d, e}$ Mean values with unlike letters were significantly different $(P<0.05)$. FA, fatty acids. proportion did not significantly differ in $\mathrm{PE}$ beyond $4 \mathrm{~d}$ (Fig. 2(C) and (D)). As observed in the liver, DHA proportions in $\mathrm{PE}$ and $\mathrm{PC}$ no longer differed from those found in the control mice after a $16 \mathrm{~d}$ washout period.

As shown in Figs. 2 and 3, proportions of DHA in both phospholipids of the control mice were lower in WAT than those observed in the liver and heart. The most important differences were observed for the heart and subcutaneous WAT, with more than six- and elevenfold DHA in heart PE and PC, respectively, compared with the subcutaneous WAT. In the DHA-fed mice, DHA proportions increased by 1.5 - to 2.5 -fold in the liver and heart PE and by 2.5- to 5-fold in WAT PE compared with the controls. Furthermore, the DHA proportions in WAT PC of the DHA-fed mice became fivefold higher than those found in the standard diet-fed mice, whereas DHA content in the liver and heart PC were two- and threefold higher than that found in the control mice, respectively.

The increase in DHA proportions in all tissue phospholipids in the DHA-fed mice was accompanied by decreased proportions of AA (Figs. 4 and 5). AA proportions were still significantly lower in PE and PC of retroperitoneal tissue than those observed in mice fed the standard diet after the $16 \mathrm{~d}$ washout period, although DHA was not increased any more.

EPA was not detected in the tissues of the control mice, but it was detectable in tissue phospholipids of the DHA-fed mice (Figs. 6 and 7).

Effects of dietary DHA on cytokines secretion, adipose tissue content and expression

We examined the effects of DHA on the production of adiponectin and leptin, which are two cytokines known to participate in the regulation of insulin sensitivity. As shown in Fig. 8(A), plasma level of adiponectin was significantly increased (by 2.4-fold) as early as $4 \mathrm{~d}$ after the initiation of the DHA-enriched diet feeding. These effects were long lasting in that the adiponectin secretion was still significantly higher than that observed in mice fed the standard diet after the $16 \mathrm{~d}$ washout period. On the contrary, blood leptin secretion was decreased by dietary DHA (Fig. 8(B)) by 1.6-fold after $4 \mathrm{~d}$ of high-DHA diet feeding. When the DHA-enriched diet was replaced with the standard diet for $16 \mathrm{~d}$, the decrease in leptin secretion was still observed compared with the control mice.

We also directly measured the content of adiponectin and leptin in AT on day 4. In all three WAT, subcutaneous, epididymal and retroperitoneal tissues, the adipokine content was not significantly different between mice fed the DHA-rich diet and mice fed the standard diet (Fig. 9). However, the adiponectin content was dependent on AT depot, with the epididymal AT showing the highest content of adiponectin both in the control mice and in the DHA-fed mice. Adiponectin gene expression was significantly increased in the epididymal and subcutaneous tissues of the DHA-fed mice than in those of the control mice, with the increase of adiponectin gene expression being more pronounced in the epipidymal AT than in the subcutaneous AT (2.2- and 1.5-fold increase, respectively). In the case of leptin, no significant effect was found in all three WAT leptin gene expressions between mice fed the DHA-rich diet and mice fed the standard diet (unpublished results). 

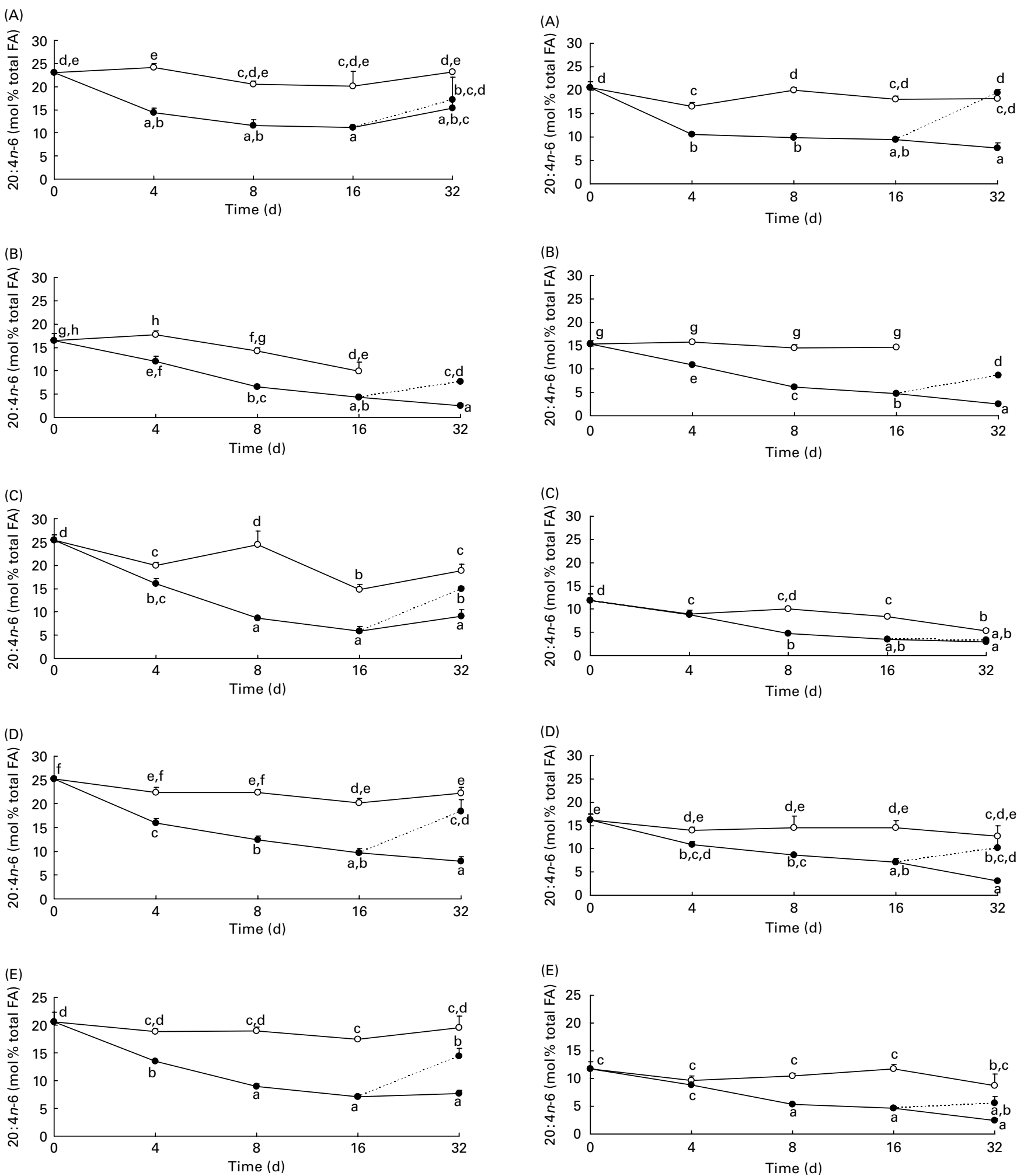

Fig. 4. 20:4n-6 proportions in phosphatidylethanolamine from liver (A), heart (B) and subcutaneous (C), epididymal (D) and retroperitoneal adipose tissues $(\mathrm{E})$ of mice fed a standard diet (control group -O-) and a DHA-rich diet (DHA group - - ) or mice fed a DHA-rich diet for the first $16 \mathrm{~d}$ and then the standard diet for the last $16 \mathrm{~d}$ (washout (WO) group --0--). Mice were killed on days $0,4,8,16$ and 32 . Results are means with their standard errors $(n 4)$. a,b,c,d,e,f,g,h Mean values with unlike letters were significantly different $(P<0.05)$. FA, fatty acids.

Fig. 5. 20:4n-6 proportions in phosphatidylcholine from liver (A), heart (B) and subcutaneous (C), epididymal (D) and retroperitoneal adipose tissues (E) of mice fed a standard diet (control group -O-) and a DHA-rich diet (DHA group --) or mice fed a DHA-rich diet for the first $16 \mathrm{~d}$ and then the standard diet for the last $16 \mathrm{~d}$ (washout (WO) group --0--). Mice were killed on days $0,4,8,16$ and 32 . Results are means with their standard errors $(n 4)$. ${ }^{\mathrm{a}, \mathrm{b}, \mathrm{c}, \mathrm{d}, \mathrm{e}, \mathrm{g}}$ Mean values with unlike letters were significantly different $(P<0.05)$. FA, fatty acids. 


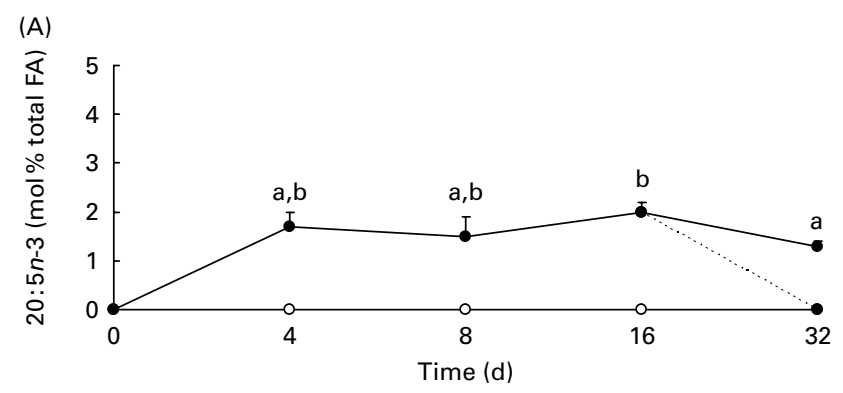

(B)

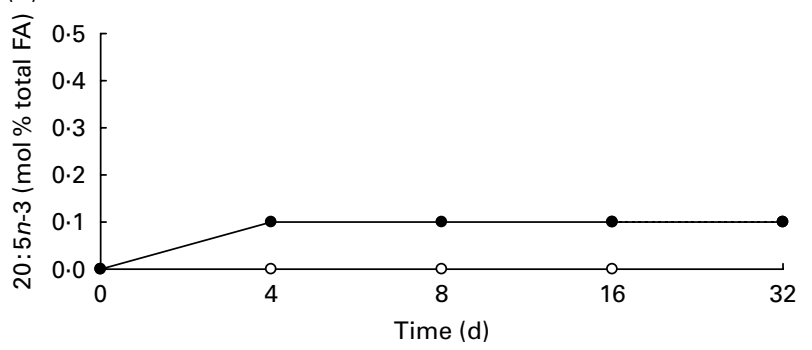

(C)
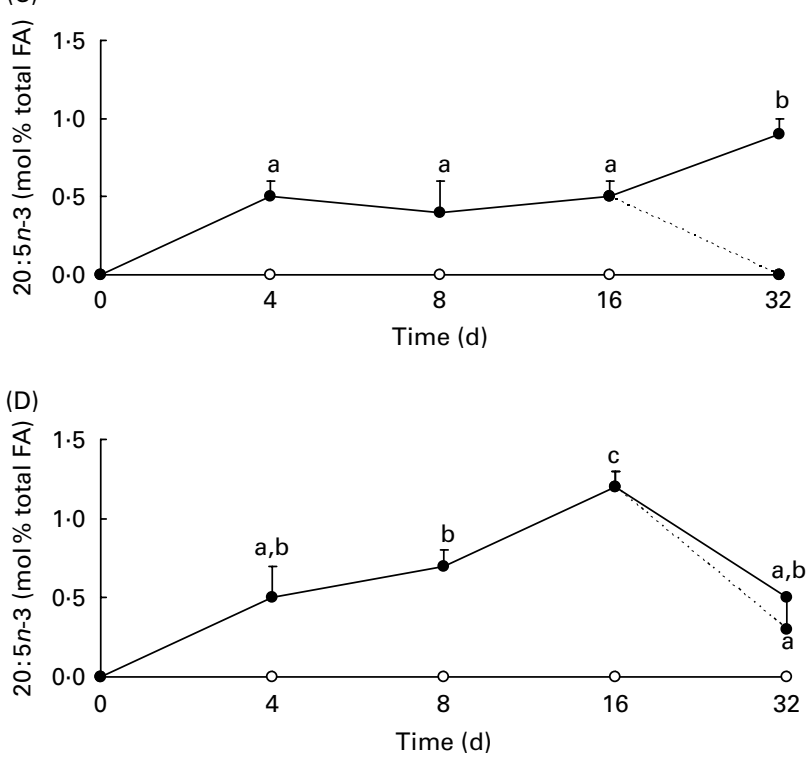

(E)

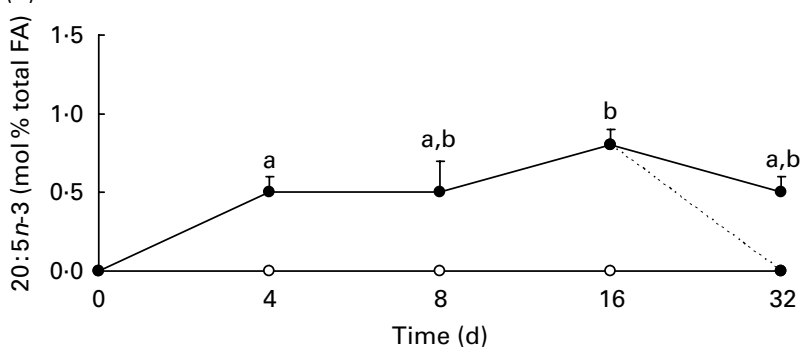

Fig. 6. 20:5n-3 proportions in phosphatidylethanolamine from liver (A), heart (B) and subcutaneous (C), epididymal (D) and retroperitoneal adipose tissues $(E)$ of mice fed a standard diet (control group -O-) and a DHA-rich diet (DHA group - -) or mice fed a DHA-rich diet for the first $16 \mathrm{~d}$ and then the standard diet for the last $16 \mathrm{~d}$ (washout (WO) group --- - -). Mice were killed on days $0,4,8,16$ and 32 . Results are means with their standard errors $(n 4) .{ }^{a, b}$ Mean values with unlike letters are significantly different $(P<0.05)$. FA, fatty acids.
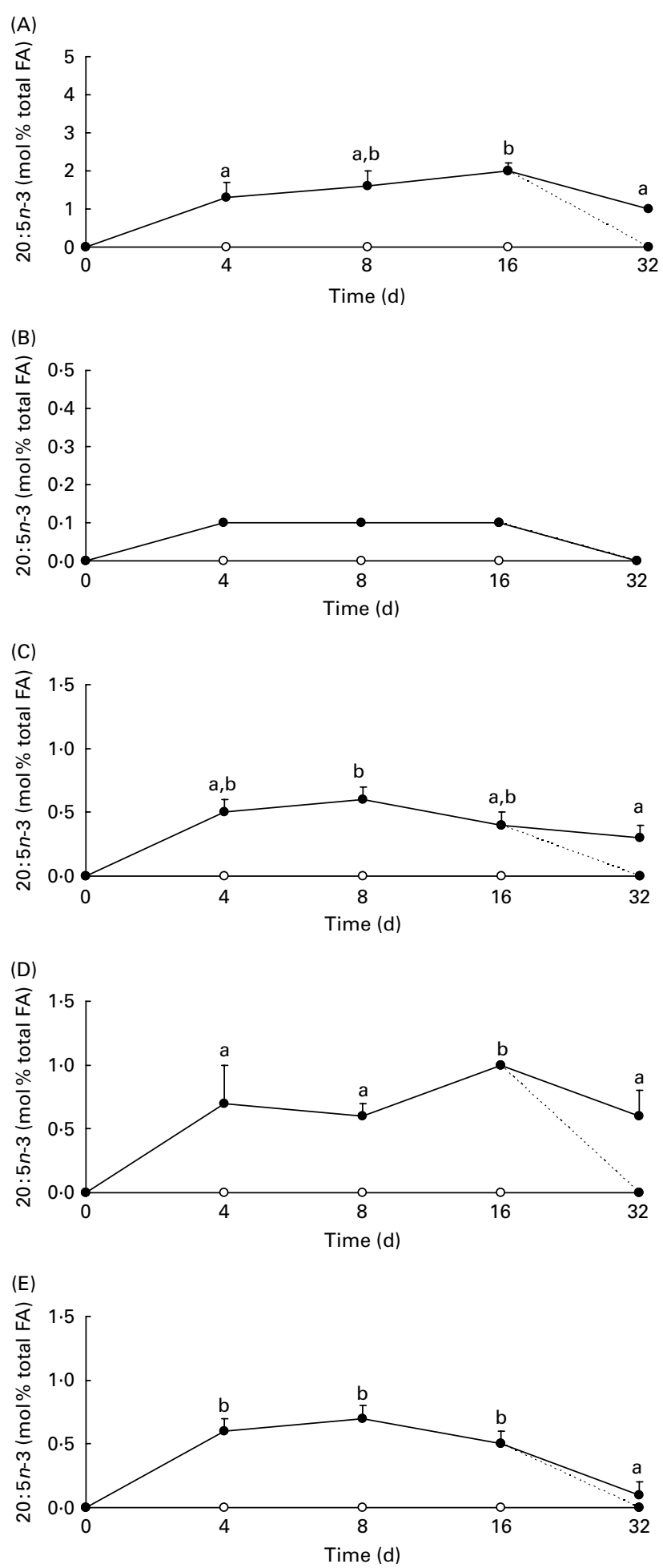

Fig. 7. $20: 5 n-3$ proportions in phosphatidylcholine from liver $(A)$, heart $(B)$ and subcutaneous $(C)$, epididymal (D) and retroperitoneal adipose tissues (E) of mice fed a standard diet (control group -O-) and a DHA-rich diet (DHA group --) or mice fed a DHA-rich diet for the first $16 \mathrm{~d}$ and then the standard diet for the last $16 \mathrm{~d}$ (washout (WO) group --0--). Mice were killed on days $0,4,8,16$ and 32 . Results are means with their standard errors $(n 4){ }^{a, b}$ Mean values with unlike letters are significantly different $(P<0.05)$. FA, fatty acids. 


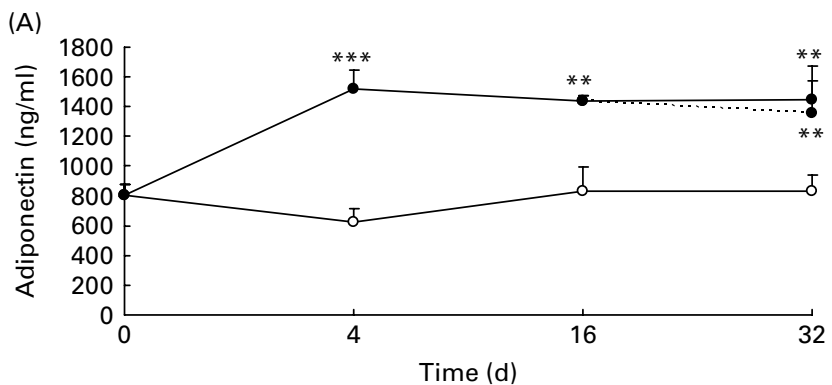

(B)

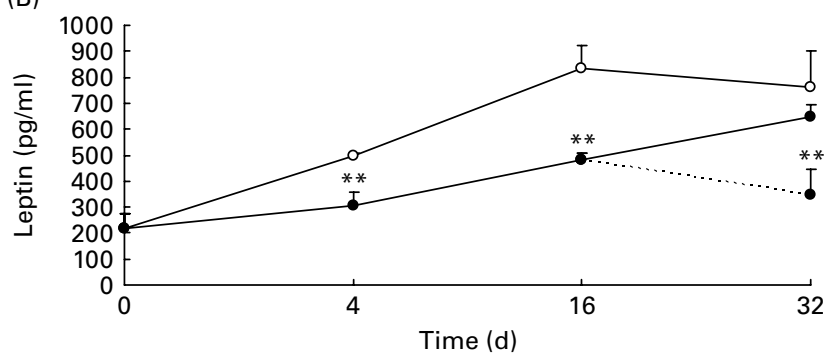

Fig. 8. Plasma levels of adiponectin (A) and leptin (B) of mice fed a standard diet (control group -O-) and a DHA-rich diet (DHA group - $\bullet-$ ) or mice fed a DHA-rich diet for the first $16 \mathrm{~d}$ and then the standard diet for the last $16 \mathrm{~d}$ (washout (WO) group -----). Plasma levels are expressed in $\mathrm{ng} / \mathrm{ml}$ and $\mathrm{pg} / \mathrm{ml}$ for adiponectin and leptin, respectively. Results are means with their standard errors $(n 4)$. Mean values were significantly different compared with the control group: ${ }^{\star \star} P<0.01$ and ${ }^{* \star *} P<0.001$.
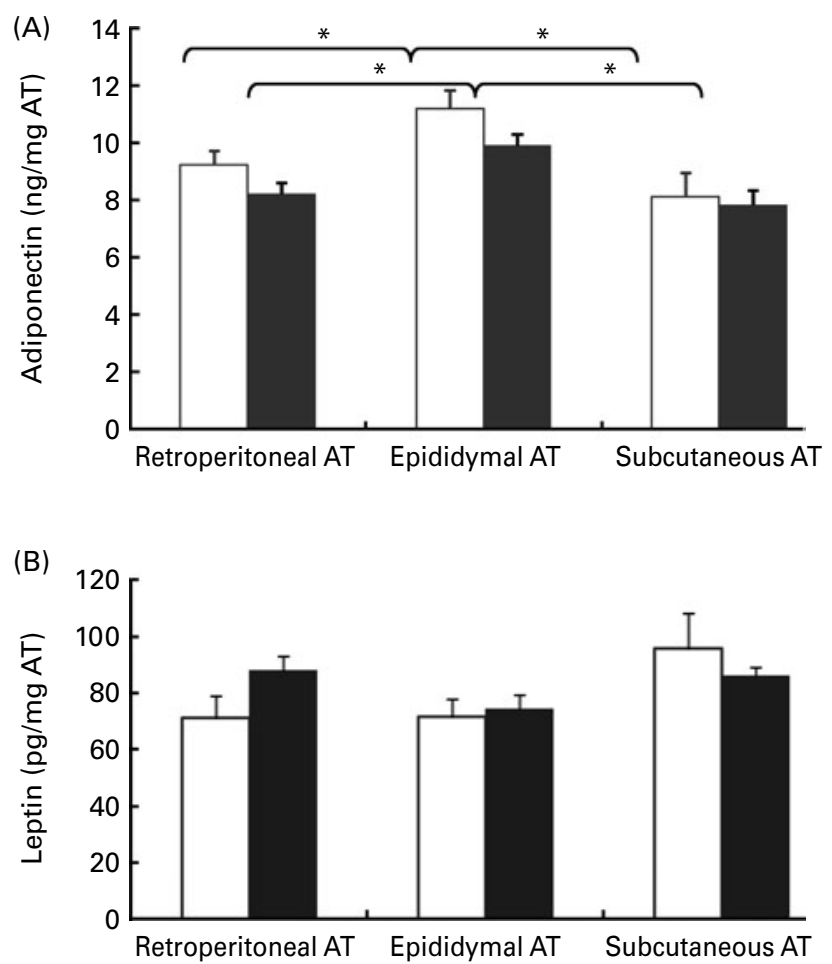

Fig. 9. Adiponectin (A) and leptin (B) protein contents in epididymal, retroperitoneal and subcutaneous white adipose tissues (AT) of mice fed a standard diet (control group $\square$ ) or mice fed a DHA-rich diet (DHA group $\square$ ) for $4 \mathrm{~d}$. Adiponectin and leptin contents of AT are expressed in $\mathrm{ng} / \mathrm{mg}$ AT and $\mathrm{pg} / \mathrm{mg}$ AT for adiponectin and leptin, respectively. Results are means with their standard errors $(n 8)$. Mean values were significantly different compared with the control group: ${ }^{*} P<0.05$.

\section{Discussion}

In the present study, we demonstrated that DHA increased adiponectin secretion in mice fed the DHA-rich diet than in mice fed the standard diet. The only previous study that investigated the effect of DHA on adipocytokine secretion was conducted over an 8-week feeding period ${ }^{(24)}$. The present results show that this increase was significant as early as $4 \mathrm{~d}$ after the initiation of the DHA-enriched diet feeding. In addition, the DHA-rich diet decreased serum leptin concentration. Interestingly, we have shown for the first time that these protective effects of DHA were maintained even after the arrest of the DHA-rich diet feeding, since plasma concentrations of adiponectin and leptin remained higher and lower, respectively, compared with the mice fed the control diet. Adiponectin is one of the most abundant plasma protein adipocytokines, essentially expressed in AT, able to protect against the development of atherosclerosis and insulin resistance. Indeed, it has been well documented that plasma adiponectin concentration is decreased in patients with coronary artery disease risks including type 2 diabetes and obesity $^{(13,14,25)}$. We found these beneficial effects to be associated with increased incorporation of DHA in PE and PC of all analysed tissues, although the WAT showed the highest relative incorporation. These DHA proportion increases were observed after only $4 \mathrm{~d}$ of DHA-enriched diet feeding. In contrast to WAT and liver, DHA proportions were still significantly higher in both heart phospholipids than those observed in the control mice after the $16 \mathrm{~d}$ washout period, suggesting that the turnover of DHA in WAT is highest. DHA increase was also accompanied by EPA increase. Since the dietary supplement was free of EPA, this suggests that DHA was retroconverted to EPA as reported previously ${ }^{(26-28)}$. These modifications were accompanied by a decreased AA proportion in tissue phospholipids, which is consistent with previous studies that reported that DHA incorporation in cell phospholipids partly occurs at the expense of $\mathrm{AA}^{(29-31)}$. The modification of the FA pattern of membrane phospholipids can, in turn, change the cell membrane fluidity, which may affect the three-dimensional structure of membrane proteins, thereby affecting their functions ${ }^{(32-36)}$. An altered pattern of eicosanoid production might also explain the modification of the cytokine profile. Indeed, the increase in phospholipid DHA content decreases the synthesis of AA-derived eicosanoids. In general, eicosanoids derived from $n$-3 LC-PUFA have anti-inflammatory effects, while those produced from $n-6$ PUFA have pro-inflammatory effects ${ }^{(37)}$. Additionally, novel bioactive lipid mediators generated from $n$-3 LC-PUFA, named resolvins and protectins, have also been shown to possess potent anti-inflammatory effects mediating the beneficial actions of $n-3 \mathrm{LC}-P U F A^{(5,38)}$. The effect of $n-3$ LC-PUFA on adiponectin secretion may also be mediated through their action as ligands of PPAR $\gamma^{(23)}$.

The results presented here also confirm the reports of previous studies that showed marked differences in relative concentrations of DHA between different tissues ${ }^{(39)}$, and clearly show their diverse responses after DHA intake. Phospholipids from heart had the highest basal DHA proportion than those from other organs, whereas AT phospholipids had the lowest. This may explain why AT showed the highest relative change in DHA proportion after the DHA-rich diet feeding. 
This is consistent with previous studies in rodents and human subjects which reported that despite the relatively small amount of DHA in $\mathrm{AT}^{(40-42)}$, they provide high capacity storage for $n$-3 LC-PUFA $^{(42)}$. It may be noted that the AT containing the highest DHA proportion, the epididymal AT, is the one containing the highest adiponectin level both in mice fed a standard diet and in mice fed a DHA-rich diet. The present results also show that ingestion of DHA had no effect on tissue adiponectin and leptin contents. We also found clear different adiponectin gene expression responsiveness to DHA in the three AT, with adiponectin mRNA expression being stronger in the epididymal AT than in the retroperitoneal and subcutaneous tissues in accordance with previous studies $^{(16,23,43)}$ (data not shown). This suggests that the stimulation of adiponectin gene expression, especially in epididymal AT, leads to increased adiponectin secretion. Conflicting data on the effects of $n-3$ LC-PUFA on adiponectin gene expression are found in the literature. This may be explained by the composition of the diet, the duration of treatment and the amount of $n-3$ LC-PUFA in the diet ${ }^{(44)}$.

The present study has also shown that the DHA-fed mice group had lower weight gain than the control group. This is consistent with previous studies that indicated that ingestion of fish oil or enrichment of the diet with EPA/DHA elicited significant reduction in mice body weight gain ${ }^{(45,46)}$. Additionally, in human studies, Kunesová et $a l .^{(47)}$ showed enhanced weight loss in response to $n-3$ LC-PUFA in obese women given a very low energetic diet. A previous study has also suggested a reduction of body fat mass after dietary fish oil intake in healthy adults ${ }^{(48)}$. The effect of DHA on weight body loss may be caused by an increase in FA oxidation and by suppression of lipogenesis in several tissues. $n$-3 LC-PUFA have indeed been shown to reduce the expression of genes encoding lipogenic enzymes in hepatic cells or liver ${ }^{(49,50)}$. DHA also down-regulates lipogenic genes in $\mathrm{AT}^{(51-54)}$. In addition, $n$-3 LC-PUFA play an important role in the regulation of genes involved in FA oxidation in muscle and liver ${ }^{(51,53,55,56)}$. Interestingly, it was demonstrated that weight loss resulted in increased plasma concentrations of adiponectin ${ }^{(13,57,58)}$.

In conclusion, the present results provide evidence to support a role of DHA in reducing weight gain associated with an improvement of the adipokine profile. The present results also show that DHA has beneficial effects on adipokine production as early as $4 \mathrm{~d}$ after the initiation of the DHA-rich diet feeding. The present study confirms that dietary intake of DHA may be beneficial for the prevention or treatment of CVD and obesity-associated disease. Few studies have been carried out on $n-3$ enrichment kinetics. The present results show that DHA enrichment and effects on adipokines are very fast. Furthermore, the beneficial effects of DHA-rich diet on adipokines lasted longer than the diet.

\section{Acknowledgements}

The present work was supported by INSERM and a grant from the French Artery and Heart Foundation (http://www. fondacoeur.com). We thank Dr J. P. Bastard for assistance with the cytokine measurements in adipose tissues. All the authors state that there are no conflicts of interest. The contribution of each author is as follows: J. L., A. G. and N. B.-H. performed the experiments; J. L. and N. B.-H. wrote the manuscript; A. G., H. V., M. L. and N. B.-H. designed the study.

\section{References}

1. Schmidt EB, Skou HA, Christensen JH, et al. (2000) N-3 fatty acids from fish and coronary artery disease: implications for public health. Public Health Nutr 3, 91-98.

2. Connor WE (2000) Importance of $n-3$ fatty acids in health and disease. Am J Clin Nutr 71, 171S-175S.

3. Holub BJ (2002) Clinical nutrition: 4. Omega-3 fatty acids in cardiovascular care. CMAJ 166, 608-615.

4. Flachs P, Rossmeisl M, Bryhn M, et al. (2009) Cellular and molecular effects of $n-3$ polyunsaturated fatty acids on adipose tissue biology and metabolism. Clin Sci (Lond) 116, 1-16.

5. González-Périz A, Horrillo R, Ferré N, et al. (2009) Obesityinduced insulin resistance and hepatic steatosis are alleviated by omega- 3 fatty acids: a role for resolvins and protectins. FASEB J 23, 1946-1957.

6. al-Shurbaji A, Larsson-Backström C, Berglund L, et al. (1991) Effect of $n$-3 fatty acids on the key enzymes involved in cholesterol and triglyceride turnover in rat liver. Lipids 26, 385-389.

7. Flachs P, Horakova O, Brauner P, et al. (2005) Polyunsaturated fatty acids of marine origin upregulate mitochondrial biogenesis and induce beta-oxidation in white fat. Diabetologia $\mathbf{4 8}$, $2365-2375$.

8. Jump DB (2004) Fatty acid regulation of gene transcription. Crit Rev Clin Lab Sci 41, 41-78.

9. Díez JJ \& Iglesias P (2003) The role of the novel adipocytederived hormone adiponectin in human disease. Eur $J$ Endocrinol 148, 293-300.

10. Arita Y, Kihara S, Ouchi N, et al. (1999) Paradoxical decrease of an adipose-specific protein, adiponectin, in obesity. Biochem Biophys Res Commun 257, 79-83.

11. Nawrocki AR, Rajala MW, Tomas E, et al. (2006) Mice lacking adiponectin show decreased hepatic insulin sensitivity and reduced responsiveness to peroxisome proliferator-activated receptor gamma agonists. J Biol Chem 281, 2654-2660.

12. Shklyaev S, Aslanidi G, Tennant M, et al. (2003) Sustained peripheral expression of transgene adiponectin offsets the development of diet-induced obesity in rats. Proc Natl Acad Sci U S A 100, 14217-14222.

13. Hotta K, Funahashi T, Arita Y, et al. (2000) Plasma concentrations of a novel, adipose-specific protein, adiponectin, in type 2 diabetic patients. Arterioscler Thromb Vasc Biol 20, 1595-1599.

14. Ryan AS, Berman DM, Nicklas BJ, et al. (2003) Plasma adiponectin and leptin levels, body composition, and glucose utilization in adult women with wide ranges of age and obesity. Diabetes Care 26, 2383-2388.

15. Bruun JM, Lihn AS, Verdich C, et al. (2003) Regulation of adiponectin by adipose tissue-derived cytokines: in vivo and in vitro investigations in humans. Am J Physiol Endocrinol Metab 285, E527-E533.

16. Flachs P, Mohamed-Ali V, Horakova O, et al. (2006) Polyunsaturated fatty acids of marine origin induce adiponectin in mice fed a high-fat diet. Diabetologia 49, 394-397.

17. Krebs JD, Browning LM, McLean NK, et al. (2006) Additive benefits of long-chain $n-3$ polyunsaturated fatty acids and weight-loss in the management of cardiovascular disease risk in overweight hyperinsulinaemic women. Int J Obes (Lond) 30, 1535-1544.

18. Ahima RS \& Flier JS (2000) Leptin. Annu Rev Physiol 62, 413-437.

19. Sader S, Nian M \& Liu P (2003) Leptin: a novel link between obesity, diabetes, cardiovascular risk, and ventricular hypertrophy. Circulation 108, 644-646.

20. Janik JE, Curti BD, Considine RV, et al. (1997) Interleukin 1 alpha increases serum leptin concentrations in humans. J Clin Endocrinol Metab 82, 3084-3086.

21. Grunfeld C, Zhao C, Fuller J, et al. (1996) Endotoxin and cytokines induce expression of leptin, the ob gene product, in hamsters. J Clin Invest 97, 2152-2157. 
22. Francis J, MohanKumar PS, MohanKumar SM, et al. (1999) Systemic administration of lipopolysaccharide increases plasma leptin levels: blockade by soluble interleukin-1 receptor. Endocrine 10, 291-295.

23. Neschen S, Morino K, Rossbacher JC, et al. (2006) Fish oil regulates adiponectin secretion by a peroxisome proliferatoractivated receptor-gamma-dependent mechanism in mice. Diabetes 55, 924-928.

24. Vemuri M, Kelley DS, Mackey BE, et al. (2007) Docosahexaenoic acid (DHA) but not eicosapentaenoic acid (EPA) prevents trans-10, cis-12 conjugated linoleic acid (CLA)induced insulin resistance in mice. Metab Syndr Relat Disord 5, 315-322.

25. Ouchi N, Kihara S, Arita Y, et al. (1999) Novel modulator for endothelial adhesion molecules: adipocyte-derived plasma protein adiponectin. Circulation 100, 2473-2476.

26. Von Schacky C \& Weber PC (1985) Metabolism and effects on platelet function of the purified eicosapentaenoic and docosahexaenoic acids in humans. Clin Invest 76, 2446-2450.

27. Brossard N, Croset M, Pachiaudi C, et al. (1996) Retroconversion and metabolism of $\left[{ }^{13} \mathrm{C}\right] 22: 6 n-3$ in humans and rats after intake of a single dose of $\left[{ }^{13} \mathrm{C}\right] 22: 6 n$-3-triacylglycerols. Am J Clin Nutr 64, 577-586.

28. Stark KD \& Holub BJ (2004) Differential eicosapentaenoic acid elevations and altered cardiovascular disease risk factor responses after supplementation with docosahexaenoic acid in postmenopausal women receiving and not receiving hormone replacement therapy. Am J Clin Nutr 79, 765-773.

29. Lands WE, Libelt B, Morris A, et al. (1992) Maintenance of lower proportions of $(n-6)$ eicosanoid precursors in phospholipids of human plasma in response to added dietary (n-3) fatty acids. Biochim Biophys Acta 1180, 147-162.

30. Sperling RI, Benincaso AI, Knoell CT, et al. (1993) Dietary $\omega-3$ polyunsaturated fatty acids inhibit phosphoinositide formation and chemotaxis in neutrophils. J Clin Invest 91, 651-660.

31. Mebarek S, Ermak N, Benzaria A, et al. (2009) Effects of increasing docosahexaenoic acid intake in human healthy volunteers on lymphocyte activation and monocyte apoptosis. $\mathrm{Br} \mathrm{J}$ Nutr 101, 852-858.

32. Holte LL, Separovic F \& Gawrisch K (1996) Nuclear magnetic resonance investigation of hydrocarbon chain packing in bilayers of polyunsaturated phospholipids. Lipids 31, S199-S203.

33. Stubbs CD \& Smith AD (1984) The modification of mammalian membrane polyunsaturated fatty acid composition in relation to membrane fluidity and function. Biochim Biophys Acta 779, 89-137.

34. Hashimoto M, Hossain S \& Shido O (2006) Docosahexaenoic acid but not eicosapentaenoic acid withstands dietary cholesterol-induced decreases in platelet membrane fluidity. Mol Cell Biochem. 293, 1-8.

35. Siener R, Alteheld B, Terjung B, et al. (2010) Change in the fatty acid pattern of erythrocyte membrane phospholipids after oral supplementation of specific fatty acids in patients with gastrointestinal diseases. Eur J Clin Nutr 64, 410-418.

36. Yehuda S, Rabinovitz S \& Mostofsky DI (1999) Essential fatty acids are mediators of brain biochemistry and cognitive functions. J Neurosci Res 56, 565-570.

37. James MJ, Gibson RA \& Cleland LG (2000) Dietary polyunsaturated fatty acids and inflammatory mediator production. Am J Clin Nutr 71, 1 Suppl., 343S-348S.

38. Serhan CN, Gotlinger K, Hong S, et al. (2004) Resolvins, docosatrienes, and neuroprotectins, novel omega-3-derived mediators, and their aspirin-triggered endogenous epimers: an overview of their protective roles in catabasis. Prostaglandins Other Lipid Mediat 73, 155-172.

39. Charnock JS, Abeywardena MY, Poletti VM, et al. (1992) Differences in fatty acid composition of various tissues of the marmoset monkey (Callithrix jacchus) after different lipid supplemented diets. Comp Biochem Physiol Comp Physiol 101, 387-393.

40. Andersen LF, Solvoll K, Johansson LR, et al. (1999) Evaluation of a food frequency questionnaire with weighed records, fatty acids, and alpha-tocopherol in adipose tissue and serum. Am J Epidemiol 150, 75-87.

41. Geerling BJ, v Houwelingen AC, Badart-Smook A, et al. (1999) Fat intake and fatty acid profile in plasma phospholipids and adipose tissue in patients with Crohn's disease, compared with controls. Am J Gastroenterol 94, 410-417.

42. Kopecky J, Rossmeisl M, Flachs P, et al. (2009) n-3 PUFA: bioavailability and modulation of adipose tissue function. Proc Nutr Soc. 68, 361-369.

43. Einstein FH, Atzmon G, Yang XM, et al. (2005) Differential responses of visceral and subcutaneous fat depots to nutrients. Diabetes 54, 672-678.

44. Bueno AA, Oyama LM, de Oliveira C, et al. (2008) Effects of different fatty acids and dietary lipids on adiponectin gene expression in 3T3-L1 cells and C57BL/6J mice adipose tissue. Pflugers Arch. 455, 701-709.

45. Mori T, Kondo H, Hase T, et al. (2007) Dietary fish oil upregulates intestinal lipid metabolism and reduces body weight gain in C57BL/6J mice. J Nutr 137, 2629-2634.

46. Ruzickova J, Rossmeisl M, Prazak T, et al. (2004) Omega-3 PUFA of marine origin limit diet-induced obesity in mice by reducing cellularity of adipose tissue. Lipids 39, 1177-1185.

47. Kunesová M, Braunerová R, Hlavatý $\mathrm{P}$, et al. (2006) The influence of $n-3$ polyunsaturated fatty acids and very low calorie diet during a short-term weight reducing regimen on weight loss and serum fatty acid composition in severely obese women. Physiol Res 55, 63-72.

48. Couet C, Delarue J, Ritz P, et al. (1997) Effect of dietary fish oil on body fat mass and basal fat oxidation in healthy adults. Int $J$ Obes Relat Metab Disord 21, 637-643.

49. Xu J, Nakamura MT, Cho HP, et al. (1999) Sterol regulatory element binding protein-1 expression is suppressed by dietary polyunsaturated fatty acids. A mechanism for the coordinate suppression of lipogenic genes by polyunsaturated fats. $J$ Biol Chem 274, 23577-23583.

50. Yahagi N, Shimano H, Hasty AH, et al. (1999) Crucial role of sterol regulatory element-binding protein-1 in the regulation of lipogenic gene expression by polyunsaturated fatty acids. $J$ Biol Chem 274, 35840-35844.

51. Raclot T, Groscolas R, Langin D, et al. (1997) Site-specific regulation of gene expression by $n-3$ polyunsaturated fatty acids in rat white adipose tissues. J Lipid Res 38, 1963-1972.

52. Azain MJ (2004) Role of fatty acids in adipocyte growth and development. J Anim Sci 82, 916-924.

53. Lapillonne A, Clarke SD \& Heird WC (2004) Polyunsaturated fatty acids and gene expression. Curr Opin Clin Nutr Metab Care 7, 151-156.

54. Takahashi Y \& Ide T (1999) Effect of dietary fats differing in degree of unsaturation on gene expression in rat adipose tissue. Ann Nutr Metab 43, 86-97.

55. Reddy JK \& Mannaerts GP (1994) Peroxisomal lipid metabolism. Annu Rev Nutr 14, 343-370.

56. Nakatani T, Tsuboyama-Kasaoka N, Takahashi M, et al. (2002) Mechanism for peroxisome proliferator-activated receptor-alpha activator-induced up-regulation of UCP2 mRNA in rodent hepatocytes. J Biol Chem 277, 9562-9569.

57. Yang WS, Lee WJ, Funahashi T, et al. (2001) Weight reduction increases plasma levels of an adipose-derived anti-inflammatory protein, adiponectin. J Clin Endocrinol Metab 86, 3815-3819.

58. Bruun JM, Lihn AS, Verdich C, et al. (2003) Regulation of adiponectin by adipose tissue-derived cytokines: in vivo and in vitro investigations in humans. Am J Physiol Endocrinol Metab 285, E527-E533. 